\title{
The Strange Use of דגל in Song of Songs 5:10
}

\begin{abstract}
The use of the word דגל in the Song of Songs 5:10 has caused considerable confusion among commentators. Most occurrences of the word in the Song are thought to be related to an army or host carrying banners, except in 5:10, where this usage is said to make little sense. Scholars therefore interpret the woman's use of דגל 5:10 differently from when the man uses it to describe her awe-striking an unnerving appearance in 6:4 and 6:10. This has given some the impression that the lovers view each other differently. This article attempts to show that the description of דגל in 6:4 and 6:10 actually illuminates its meaning in 5:10, so that when the woman uses it to describe the physical appearance of the man, it communicates similar feelings of awe and fear, that is, an awestriking and unnerving appearance.
\end{abstract}

Key Words: $d g l$ - awe - reverent fear - physical attraction

The word דגל is used by both the man and the woman in the Song of Songs to describe the physical appearance of the other lover. However, commentators often interpret the meaning of the word in 5:10 differently from when it occurs in 6:4 and 6:10. In 6:4 and

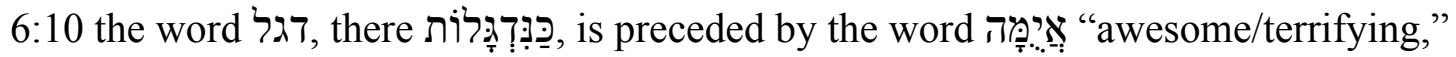
and is often translated "awesome as an army with banners" or "awesome as bannered hosts/visions." Most occurrences of the word דגל in the Song are seen as related to an army or host carrying banners, except in 5:10, where this usage is thought to make little 
sense, and it is instead translated as "preeminent," "standing out," "something to see" or "outstanding." This has given some the impression that the lovers view each other differently, that the man is more awestruck and intimidated by the visual sight of her physical beauty than she is of his. However, I would suggest that the description of in 6:4 and 6:10 actually illuminates its meaning in 5:10, so that when the woman uses the term to describe the physical appearance of the man it communicates similar feelings of awe and fear, that is, an awe-striking and unnerving appearance. Whilst the divergent interpretations of דגל in 6:4, 10 and 5:10 give the impression that the lovers view each other differently, they actually use the same word to describe one another and express similar feelings of intimidation in the presence of the other lover. In order to further illuminate the meaning of T⿱乛龰 in Songs 5:10 we will briefly survey the scholarly discussion before presenting a new understanding of its usage.

\section{The Discussion Thus Far}

The root דגל דגל occurs four times in the Song of Songs, in 2:4, here in 5:10, and in the man's description of the woman in $6: 4$ and $6: 10$. It is related to the "carrying of banners" by a host or army in the book of Numbers, and this is how many translate it the first time it occurs in 2:4, thus "his banner over me was love." However, that usage is thought to make little sense in the context of 5:10, so many have followed Robert Gordis in seeing a connection with the Akkadian dagālu "to see, look upon." HALOT (205) and

\footnotetext{
${ }^{1}$ Robert Gordis, “The Root דגל in the Song of Songs,” JBL 88 (1969), pp. 203-204; Robert Gordis, The Song of Songs: A Study, Modern Translation, and Commentary (New
} 
NIDOTTE (\#18400) list this meaning for דגל 5:10, the Septuagint and Vulgate seem to render it this way, and Tremper Longman calls it a "hapax use of the verb $d g l$ I." In 5:10 Michael Fox translates דָָרגוּ as "preeminent," Roland Murphy as “outstanding," Longman as "distinguished" and Cheryl Exum as "stands out" because of the particle attached to the following word רברָָ thus "something to see among ten thousand" or "standing out among ten thousand." 3 Yet, the other occurrences of the verb, in 2:4 and often in 6:4 and 6:10, are seen as related to bannered hosts. The exception is Michael Fox, who follows Marvin Pope in comparing דִגְל 2:4 to the Akkadian cognate diglu "glance/intent/wish," thus "his intention towards me was lovemaking."4

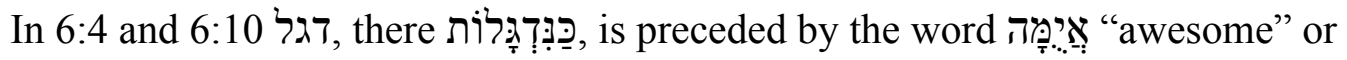
"terrifying." It is often translated as some variation of "awesome/terrible as an army with York: Jewish Theological Seminary of America, 1954), pp. 89-92; J. Cheryl Exum, Song of Songs: a Commentary (OTL; Louisville: Westminster John Knox, 2005), p. 203. 2 Tremper Longman III, Song of Songs (NICOT; Grand Rapids: Eerdmans, 2001), p. 170;

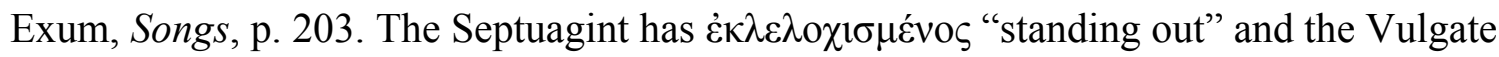
electus "distinguished."

${ }^{3}$ Michael V. Fox, The Song of Songs and the Ancient Egyptian Love Songs (Madison: University of Wisconsin Press, 1985), p. 140; Roland E. Murphy, The Song of Songs (Hermeneia; Minneapolis: Augsburg Fortress, 1990), p. 164; Exum, Songs, p. 203; Longman, Songs, p.163.

${ }^{4}$ Fox, Songs, 108; Marvin H. Pope, Song of Songs: a New Translation With Introduction and Commentary (AB; Garden City, NY: Doubleday, 1977), p. 376. 
banners" or "awesome/terrible as hosts," and the Septuagint and Vulgate translate similarly. ${ }^{5}$ The exceptions are those who retain the Akkadian meaning of "to see, look at": Murphy who translates "visions" so "awe-inspiring as visions," Fox who thinks the article indicates a superlative so "awesome as the most eminent/conspicuous," Pope who thinks that the circumstances suggest "visual objects of distinctive, spectacular character" thus "trophies," and Exum who attempts to retain both meanings of דגל with "splendour,"

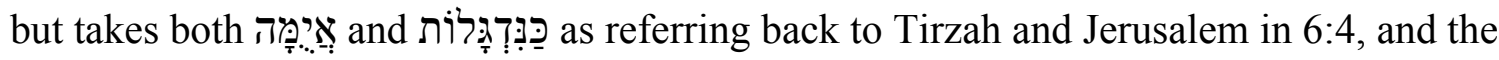
moon and the sun in 6:10, thus "awesome in splendour as they."6

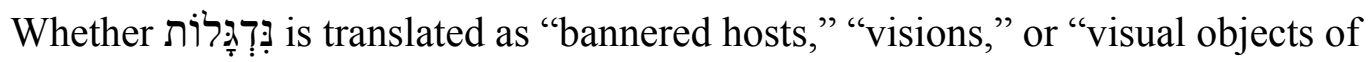
spectacular character," all commentators agree that it is awe-striking or awesome in appearance, so much so that it is intimidating and almost fearful, for he asks her to turn

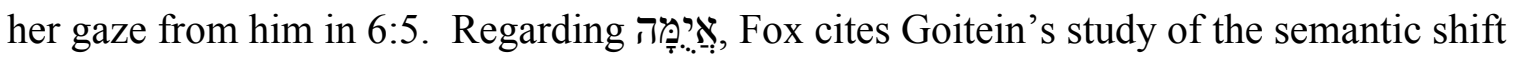
of several words in various languages from the sense of "causing fear, terrible" to "terrific, extraordinary," and explains that these words do not lose their original meaning

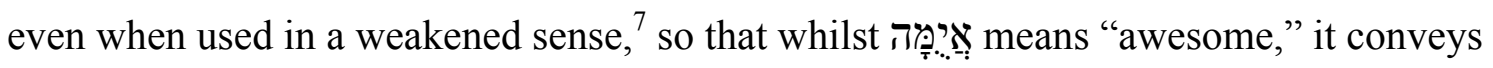

\footnotetext{
${ }^{5}$ Exum, Songs, p. 212. The Septuagint has $\theta \alpha \dot{\alpha} \beta \beta_{\varsigma} \omega \varsigma \tau \varepsilon \tau \alpha \gamma \mu \varepsilon \dot{v} \alpha \mathrm{l}$ "terrible as [armies] set in order" and the Vulgate terribilis ut castrorum acies ordinata "terrible as ordered army camps."
}

${ }^{6}$ Murphy, Songs, p. 174; Fox, Songs, p. 152; Pope, Songs, p. 561; Exum, Songs, pp. 210 , 212 note a.

${ }^{7}$ Fox, p. 151; S. D. Goitein, “Ayumma Kannidgalot (Song of Songs VI. 10),” JSS 10 (1965), pp. 220-221. Fox (Ibid) notes that this happened, for example, with the English 
feelings of both fear and wonder. The adjective 1:7 to describe the terrible/awe-inspiring and dreaded Chaldeans who march across the earth conquering all in their path, and the related noun אֵימָ also refers to something awesome or terrifying, as well as the feelings of awe, fear or dread that it inspires in the person viewing it. ${ }^{8}$ The point is that the object, here in 6:4 the woman, is awe-inspiring, fearsome to behold, intimidating and unnerving.

\section{A New Understanding}

What scholars have not noticed, and what I would like to call attention to and contribute,

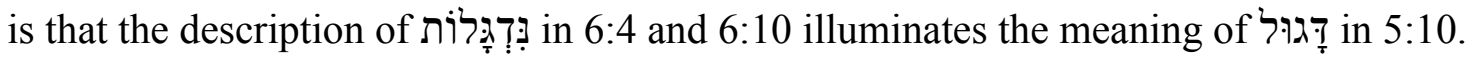

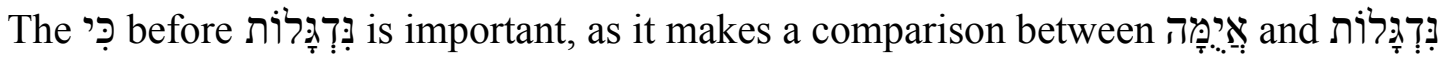
and tells us that the woman, is "awesome" or "awe-striking" as as bannered hosts are awe-striking, or as visual objects of spectacular appearance are

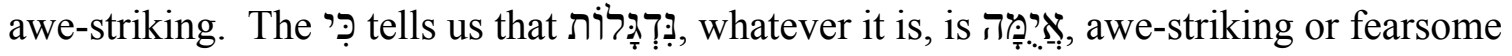
to behold, so that we know that i⿱ fearsome to behold and unnerving, conveying simultaneous feelings of both wonder and word "terrific" or the French terrible, and thinks the same is true of אָים, a word that originally meant "terrifying" and is being used in the sense of "awesome." ${ }^{8}$ Exum, Songs, p. 218, cf. Murphy, Songs, p. 175. See Exod 15:16; 23:27, Deut 32:25, Ps 55:5[H], Job 13:21;33:7; 39:20; 41:6[H] and Prov 20:2. The sight of the woman in $6: 10$ is similar to a theophany, and as Exum (Ibid) notes, these also inspire fear, dread, awe and wonder, as in Gen 15:12. 


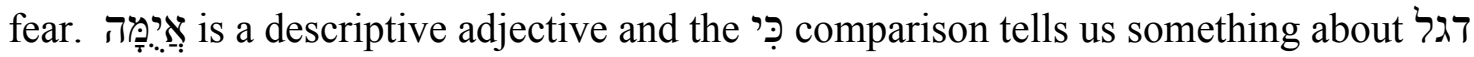
and the feelings that it arouses, so that even if we do not understand precisely what it is, we know that it inspires awe, fear and wonder. This further explicates the meaning of

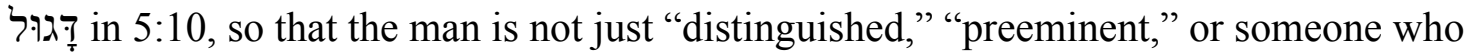
stands out, but someone so awe-striking in appearance that he stands out, even in a crowd of ten thousand. He is an "awe-inspiring vision among ten thousand," a "fearsome visual object of splendour among ten thousand" or an "awe-inspiring host (carrying banners) among ten thousand." Whatever T⿱乛龰ְ is in 5:10, it is awe-inspiring, fearsome to behold, wondrous and intimidating, and this is what makes him stand out among ten thousand. This is consistent with 1:16 where his appearance is also so unnerving that is causes her to look away from him to the bed.

Gordis actually originally noted that the Akkadian root dagālu carries a distinct nuance, so that it does not just mean "to look upon," but "to look with astonishment."9

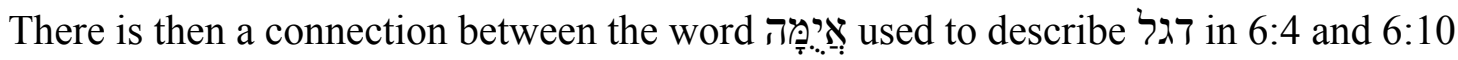
and the nuance inherent in this root itself, which both show the effect that this sight has on the viewer: it arouses feelings of astonishment, wonder, awe and fear. "Preeminent" fails to communicate the feelings that

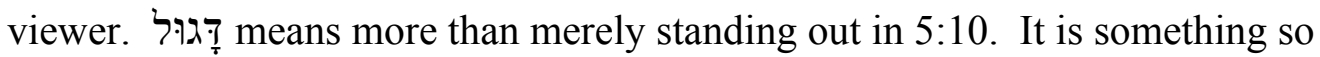
astonishing, awe-striking or captivating that it unnerves the viewer and makes the lover stand out among ten thousand.

\footnotetext{
${ }^{9}$ Gordis, “The Root דגל," p. 203. His (Ibid, 204) translation of דָָּּ as "preeminent," however, does not convey this nuance and the effect that the sight has on the viewer.
} 
One can see why bannered hosts would be awesome and unnerving at the same time. Imagine how one might feel seeing a host or army carry military banners towards them. It would be a sight to see (as the Akkadian dagālu suggests) and the sight would certainly be awe-inspiring to look at, but also a bit unnerving or intimidating in an impressive way. They would carry an element of wonder and awe, but also an element of danger or fear, as they can mean the coming of destruction. Perhaps this is the connection between the Akkadian dagālu and דגל. The military imagery of banners or bannered hosts, and the intimidating feelings that it arouses, is consistent with the other military terms and imagery that the man uses to describe the woman's beauty, for example, the impressive tower made of warrior shields in 4:4. He is certainly intimidated in 6:5 when he asks her to turn her eyes away because they unnerve him, and she has already expressed a similar idea in 1:16 where she is so unnerved by the sight of his beauty that it causes her to look away from him to their bed. As Exum observes, each phrase after in 1:16 begins with אַ “as if she were gasping for breath in wonderment."10 Just as they are awestruck by one another's beauty in 1:15 and 1:16 the same happens in 5:10, 6:4 and 6:10, and it makes sense that the lovers would use the exact same word, דגל, to describe one another and the feelings of utter awe they inspire, as their language has been reciprocal throughout the book.

Further evidence for this meaning of צִ ִָ directly before it to describe his "radiance." There are connections between words for radiance in military contexts and fear in many ancient Near Eastern texts. As numerous

10 Exum, Songs, p. 113. 
Mesopotamian parallels show, the idea of light, brightness or radiance surrounding a king or deity was a common conception in the ancient Near East, was often associated with military power and inspired both awe and terror. ${ }^{11}$ These terms for radiance were used in military contexts to convey the fearful and awe-inspiring approach of a warrior. Given the military background of the word דגל, and the appearance of רבָָה "ten thousand" directly after, which is often used in military contexts, ${ }^{12}$ the close proximity of the word צֵ likely shows that a similar idea of awe and terror is being conveyed in 5:10. This

11 Alison Grey, Psalm 18 in Words and Pictures: a Reading Through Metaphor (Leiden: Brill, 2014), pp. 94-95; See the "Sargon Chronicle" (Bill T. Arnold and Bryan E. Beyer, Readings from the Ancient Near East: Primary Sources for Old Testament Study [Grand Rapids: Baker 2002], 154), “A Hymn Celebrating Assurnasirpal II's Campaigns to the West,” translated by Victor Hurowitz (COS 1.139: 471), “Shalmaneser III: Kurkh Monolith,” translated by K. Lawson Younger, Jr. (COS 2.113A: 261), “Adad-nirari III: Saba'a Stela," translated by K. Lawson Younger, Jr. (COS 2.114E: 275), “Adad-nirari III: Calah Orthostat Slab,” translated by K. Lawson Younger, Jr. (COS 2.114G: 276), “Sargon II: Nimrud Prisms D \& E," translated by K. Lawson Younger, Jr. (COS 2.118D: 296), “Sargon II: The Small 'Summary’ Inscription,” translated by K. Lawson Younger, Jr. (COS 2.118F: 297), “Sennacherib's Siege of Jerusalem," translated by Mordechai Cogan (COS 2.119B: 302-303), “Clay Tablet No. 30” (Erle Leichty, The Royal Inscriptions of Esarhaddon, King of Assyria (680-669 BC) [RINAP 4, Winona Lake, IN: Eisenbrauns, 2011], 76).

12 See Lev 26:8, Num 10:36, Duet 32:30, Judg 20:10, 1Sam 18:7, 8; 21:12; 29:5, Ps 3:7 and 91:7. 
would be consistent with the use of דג 6:4 and 6:10. Verbs for 'shining' 'brightness' and 'radiance' are also used in 6:10 when he says that she הְַּּשְשָקָפָה 'shines' like the dawn and is דָּרָָ 'radiant' or 'bright' as the sun. This is directly before he repeats that she is

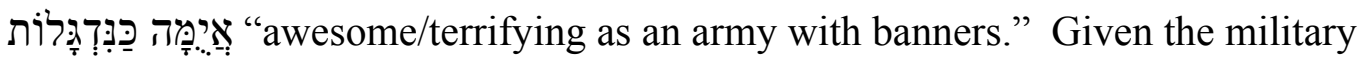
background of דגל, its use with terms for 'radiance' seems to show that it intends to convey feelings of both awe and fear in these verses. In 5:10 the man is not just 'outstanding' among ten thousand. He is awe-inspiring and fearsome to behold. There is something unnerving about his appearance, like the awe-inspiring warrior approaching in other ancient Near Eastern texts.

As many dictionaries presuppose, there are two homophonic roots of דגל: I) "to raise a standard/banner, and II) "to look upon."13 Yet, I would suggest that these roots are semantically related. All eighteen occurrences of the root denote something visual that is "looked upon," yet all usages retain a strong military aspect. The fourteen occurrences of the root דגל outside the Song of Songs are always used in military contexts. The noun is used thirteen times in Numbers to indicate a raised standard or military banner, and once in the Psalms to indicate the carrying of banners. ${ }^{14}$ As Gordis observed, a military banner is an object looked upon. ${ }^{15}$ The four other occurrences of the root are in the Song, and all have been seen as connected to military banners, except 5:10. Yet, even in 5:10 the strong military aspect of the root remains, as it is surrounded by

${ }^{13}$ HALOT, 205; NIDOTTE, \#18400.

${ }^{14}$ Num 1:52; 2:2, 3, 10, 17, 18, 25, 31, 34; 10:14, 18, 22, 15; Ps 20:6.

${ }^{15}$ Gordis, "The Root דגל," p. 204. 
words that occur in military contexts. The term רברבָז "ten thousand" is often used in military contexts, ${ }^{16}$ and this makes its parallelism with $6: 4$ and $6: 10$ more plausible. The term צִ "radiance" used before Tִָ in in 5:10 also parallels the terms used for "radiance" in 6:10, and as noted, ancient Near Eastern texts often use terms for radiance in military contexts to communicate the awe and fear of an approaching warrior. Both semantic meanings of the root are plausible for its occurrences in the Song. 2:4 might be translated "his banner over me was love" or "his fearsome/awe-striking look upon me was loving." 6:4 and 6:10 might be translated "awesome/terrifying as bannered hosts" or "awesome/terrifying as astonishing visions." 5:10 may be translated "an awe-inspiring host (carrying banners) among ten thousand" or "an awe-inspiring/fearsome vision among ten thousand." The second meaning connected with the Akkadian dagālu is probably preferable, yet רְבָָרָ "ten thousand" reminds us of the strong military aspect of the root. As Gordis originally observed, the Akkadian root carries a distinct nuance of

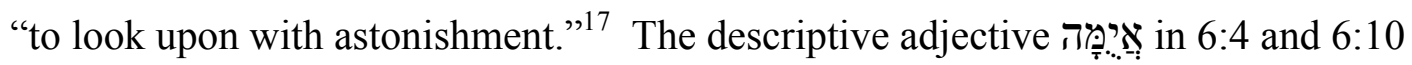
elucidates this nuance, showing that דגל is something awe-inspiring, astonishing, fearsome to behold and intimidating. This nuance, and the description that provides, should then be brought out in our definition of $d g l$ II: "to look upon with astonishment, awe, fear or wonder." As noted, military banners inspire awe, astonishment, fear and intimidation, as they are a thrilling sight to see but can mean the coming of destruction.

16 Of the fifteen times that רִרָז occurs outside the Song ten are in military contexts. 17 Gordis, “The Root דגל," p. 203. 
דגל is something awe-striking and fearsome to behold, a visual object looked upon with astonishment, wonder and intimidation. The military aspect of the root reinforces the feelings of awe and fear that the sight arouses in the person viewing it. The man in 5:10 is not just preeminent among ten thousand. He is an astonishing sight, as fearsome to behold as a bannered host or an awe-inspiring warrior approaching.

\section{Conclusion}

The use of דגin 5:10 communicates the same feelings of awe and fear as it does in 6:4 and 6:10. Just as his beauty overcame her and caused her to look away from him to their bed in 1:16, she uses the term דגל 5is 5 to communicate that his appearance is arresting, stands out, strikes awe or wonder into the person beholding it and is a bit unnerving or intimidating. He uses the same term דג 6 in $6: 4$ and 6:10, and expresses the same feelings of intimidation in 6:5 when he begs her to turn her eyes from him as they unnerve him or "make him tremble." The divergent interpretations of the way that the man and women use the term Tגל have given some the impression that the lovers view each other differently, that the man is more intimidated by her physical beauty than she is of his, when in fact, they use the same word to describe the sight of one another and the feelings of utter awe that it arouses. They use reciprocal language, as they do throughout the Song, to show that their attraction to each other is so strong that they are completely overwhelmed by the physical appearance of the other. Both lovers use the term דגל to describe the awe-striking or unnerving appearance of the other lover and both feel vulnerable in each other's presence. 